\title{
Felsőoktatás az állam kezében - Aspektusok és szerepkörök
}

\author{
Nagy-Rádli Dalma*
}

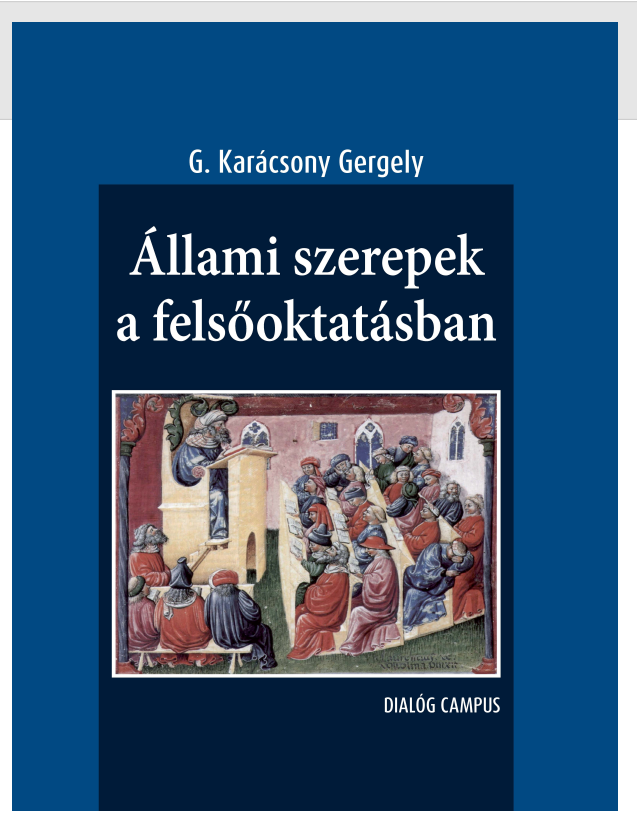

G. Karácsony Gergely (2016): Állami szerepek a felsőoktatásban. Dialóg Campus, Budapest.

Az elmúlt években számos reform történt a magyar oktatásügyben, ezek a változások pedig hatással voltak az oktatás minden szintjére, így a felsőoktatásra is. A felsőoktatásbeli változások mindenkit érintenek. Érintettek vagyunk benne természetesen mi, közvetlen szereplők, hallgatók, oktatóink, adminisztratív dolgozók, ugyanakkor jövendőbeli munkáltatóink, a munkaerőpiac más különböző szereplői, a felsőoktatásból közvetett módon profitáló személyek, s ha gazdasági távlatokban gondolkodunk, az egész társadalom (Varga, 1998). Egyre szélesebb körben terjed az a megközelítésmód, hogy a felsőoktatás és úgy általában az oktatás, - nem csupán a vele közvetlen kapcsolatba kerülő egyének szintjén, hanem össztársadalmi szinten is meghatározó, s minden tagja számára egyaránt fontos kell, hogy legyen. Az állam mindezt figyelembe véve invesztál a (felső)oktatásba, s cserébe megtérülést vár - ez nem csupán nemzetközi tendencia, hanem hazai kontextusban is tetten érhető.

Az utóbbi néhány évben a kormány számos olyan intézkedést foganatosított, amelyek átalakították a felső oktatást: a Széll Kálmán tervben is megjelenik a kormány igénye a felsőoktatási rendszer megújulása iránt ( Harsányi és Vincze, 2012). A Magyar Kormány felsőoktatási stratégiája 2030-ra irányozza elő a „felsőoktatásbeli fokozatváltást", amelynek keretein belül már olyan átalakítások léptek életbe, mint például a stratégiai célként megjelenő oktatási, kutatási, és innovációs kiválóság hármas egységének megvalósításához szükséges folyamatokat hívtak életre. A bemeneti és kimeneti követelmények változása (például a képzésbe való belépés és a diplomaszerzés nyelvvizsgához kötése), a financiális, gazdasági szerepben bekövetkezett változások (például kancellária bevezetése), az intézményrendszerek átalakítása, racionalizálása (például konzorciumok létrehozása) mind olyan esemény, amely miatt a felsőoktatás az utóbbi időben nagyobb médiavisszhangot kapott. Ez a nagyfokú érdeklődés, minden pozitív hatása ellenére is olyan ambivalens képet alakított ki a médiafogyasztókban, amely akarva-akaratlan értékítéletet mond a felsőoktatásról, s különböző téves eszmék kialakításának kedvez (Berlinger, 2011, 2013).

A tömegkommunikáció és a felsőoktatás közügyként való értelmezésének hatására egyre több forrásból értesülhetünk a napjainkban is, jelen pillanatban is zajló dinamikus változásokról. A médiában is sokszor vitatott téma, hogy meddig terjed az állam szerepe, irányítása a felsőoktatásban, tehát nem árt, ha tudományos munkára támaszkodva is megismerhetjük. G. Karácsony Gergely (2016) pedig könyvében éppen e téma mélyebb, több szempontú elemzését adja. Az Állami szerepek a felsőoktatásban című könyv aktuális olvasmány minden érdeklődő és kíváncsi olvasó számára. A szerző, G. Karácsony Gergely jogász, oktatási szakértő, tanácsadó, korábbi munkássága alatt is foglalkozott már felsőoktatással, szakterületéhez köthetően inkább jogi vonatkozásban. Azonban Állami szerepek a felsőoktatásban című doktori disszertációjából született könyvében a téma komple-

* Elsőéves neveléstudományi mesterszakos hallgató az Eötvös Loránd Tudományegyetem Pedagógiai- és Pszichológiai Karán. Email: nagy-radli.dalma@ppk.elte.hu 
xitását megragadva igyekszik interdiszciplináris módon bemutatni az állam felsőoktatásbeli szerepét. Így a mű nem csak a felsőoktatás jogi kereteibe nyújt betekintést, hanem meghatározó közgazdaságtani, oktatáspolitikai, oktatásirányítási vonatkozásban is vizsgálja a fent említett jelenségeket. A szerző stílusa - s ez jogtudományi besorolása miatt talán meghökkentőnek hathat -, könnyed, gördülékeny, a modern, naprakész példák segítségével könnyen követhető. A könyv feltételez általános jogi alapismereteket, ugyanakkor törekszik a jogi fogalmak, kifejezések magyarázatára, egyértelműsítésére. Így merem ajánlani azok számára is, akik érdeklődnek az állam és a felsőoktatás viszonya iránt, azonban ennek jogi kereteinek megismerésére, s így célzottan a jogtudományban való elmélyedésre már nem vállalkoznának.

Bevezetésként neveléstörténeti kontextusba helyezve mutatja be a felsőoktatásban bekövetkezett jogi változásokat, levezetve ezzel a felsőoktatási jog fejlődésének pályáját. Ezek rövid áttekintése után fókuszál fő témájára, az állam felsőoktatásbeli szerepvállalására. Ezt követően négy különböző szerepkört különít el: az állam szabályozó tevékenységét, az állam intézményalapító és intézményfenntartó tevékenységét, az állam finanszirozó tevékenységét és az állam minóségbiztositási tevékenységét. Ezek ismertetésére külön-külön fejezetet szán, majd minden egyes fejezet után megosztja az olvasóval konklúzióit, rövid áttekintést nyújtva ezzel a teljes fejezetnek, az adott állami szerepkörnek. Az állam szabályozó tevékenységét elemezve először az állam felsőoktatásbeli jogalkotói szerepét vizsgálja meg, különválasztva a felsőoktatás intézményi jogot, a felsőoktatásban résztvevők alanyi jogait, illetve a felsőoktatás eljárásának jogait. Az egész felsőoktatási joganyagot általános és kvalitatív módon mutatja be. A magyar felsőoktatás szabályozására ható belső tényezők megemlítésekor főként az Alaptörvényt, a Nemzeti felsőoktatási törvényt és a MAB (Magyar Akkreditációs Bizottság) munkásságát emeli ki, emellett a külső hatások is megjelennek, erre a nemzetközi irodalomban megjelent közleményeken keresztül világít rá. Az állam mint intézményalapító és intézményfenntartó fejezetben tárgyalja a felsőoktatási intézmények létesítésének lépéseit és a felsőoktatási intézmények megszűnésére vonatkozó szabályokat. $A z$ állam fenntartói feladatait részletezve listázza, ismerteti az állam intézményfenntartó jogait (költségvetési jogok, ellenőrzési jogok, személyi döntések) és kötelezettségeit, valamint szót ejt a nemrégiben bevezetett kancellária rendszeréről is. Ez az utóbbi évek nagy dilemmája a felsőoktatásban, amely során szóba kerül az intézményi autonómia kérdése is (Bárány V., 2015). Az oktatás-gazdaságtani megközelítés során ismét neveléstörténeti háttérrel magyarázza a közgazdaságtani változásokat. Az állam finanszírozási szerepéről szóló fejezetben említést tesz a bevételi források lehetőségeiről, a forráselosztási rendszerek egy általános jellemzéséről, majd ebbe beemelve az államot, a felsőoktatási intézmények pénzügyi mozgásteréről, majd hazai vonatkozásban a finanszírozási lehetőségeket és megoldásokat ismerteti. Az utolsó olyan fejezetben, amelyben a szerző a szerepeket mutatja be (Az állam minőségbiztosítási feladatai a felsóoktatásban), kezdetben európai, nemzetközi kitekintést kapunk a minőségbiztosítási rendszerekkel kapcsolatban, majd megismerhetjük az ESG hazánkkal szemben is támasztott kritériumait, majd ezt mind a belső, mind a külső minőségbiztosítási hazai jogszabályok keretén keresztül ismerteti. A könyv lezárásaként az Összegzés és értékelés fejezetben nagy vonalakban feleleveníti, hogy melyek azok a legfontosabb következtetések, amelyeket az egyes fejezetek végén megfogalmazott. Az első fejezetben áttekinthettük, hogy az állami szférán belül ki, milyen jogszabályi keretek közül jogosult arra, hogy jogalkotó legyen, majd ezt követően a szerző bemutatja a szabályozási területeket. Nagyobb csomópontokként ismerteti a felsőoktatási intézmények jogait, valamint azt is, hogy ki alkothatja meg ezeket. Az utolsó fejezetben a szerző már értékel, javaslatokat is megfogalmaz a felsőoktatásban az állami szerepvállalás átláthatóságának növelése érdekében, a finanszírozás tekintetében, valamint az intézmények alapfeladataihoz tartozó részletes költségkalkuláció fokozatosan történő bevezetését szorgalmazza. 
A könyv hiánypótló a hazai kontextusban, hiszen az állam felsőoktatásra gyakorolt hatásával, különböző nézőpontokból és tudományterületek felől már számos folyóiratcikk foglalkozott, azonban egy ilyen monográfia eddig még nem volt elérhető a nagyközönség számára. Szerencsés, hogy a különálló fejezetek értelmezéséhez nincs különösebb szükség közgazdaságtani vagy jogi ismeretekre, mivel a felmerülő fogalmakat, definíciókat a szerző legjobb igyekezete szerint igyekszik modern, a médiából is ismeretes példákkal alátámasztani, s mindezt összekapcsolni az egyes esetek jogi kontextusával, például bizonyos képzési szakok megszüntetése, oktatáspolitikai keretszámok meghatározása (bölcsészek kontra mérnökök). Fontos kritikaként többször is megfogalmazza, hogy a felsőoktatás rendszerének kellő időt kell hagyni, hogy tudatosodjanak, szokássá váljanak a reformok, s bírálja, hogy az elmúlt évek tapasztalatai szerint ez csak az esetek kis részében következett be. A szerzőből érződik az igyekezet, hogy a témát érdekessé tegye laikusok számára is, bár szerencsés, ha célcsoportja rendelkezik a felsőoktatást érintő előzetes ismeretekkel, s természetesen az ezt befolyásoló jogi-közgazdaságtani háttér ismeretével. Azonban a mű ezeknek híján is értelmezhető, világos helyzetképet ad a mai felsőoktatás dinamikusan változó kereteiről. Ajánlom e könyvet mindazoknak, akik hasonló élményekre vágynak, hallgatóknak, oktatóknak, érdeklődőknek, akik kicsit mélyebben szeretnék megismerni az állam sokrétű szerepét a felsőoktatásban, ugyanakkor nem riadnak vissza az első pillantásra száraznak tűnő jogszabályi hivatkozásoktól, közgazdaságtani ábráktól. A mű eléri célkitűzéseit - ha valaki végigolvassa ezt a könyvet, biztosan rendelkezni fog egy átfogó képpel az állam felsőoktatásbeli szerepéről.

\section{Szakirodalom}

1. Bárány V. Fanny (2015): A felsőoktatás-igazgatás rendszerének átalakítása Magyarországon. Kodifikáció és Közigazgatás. 5. 89-99.

2. Berlinger Edina (2011): Vödör a fejre. Magyar Narancs, 42. sz. URL: http://magyarnarancs.hu/publicisztika/vodor_a_fejre_-_negy_teves_eszme_a_felsooktatasrol77170\# Utolsó letöltés: 2017. május 30.

3. Berlinger Edina (2013): Elvonási tünetek - Újabb két téveszme a felsőoktatásról. Magyar Narancs. 7. sz. URL: http://magyarnarancs.hu/publicisztika/felsooktatas-berlinger-edina-elvonasi-tunetek-83591/? orderdir=novekvo Utolsó letöltés: 2017. május 30.

4. Kormány.hu (2014): Fokozatváltás a felsőoktatásban. A teljesítményelvü felsőoktatás fejlesztésének irányvonalai. URL: http://www.kormany.hu/download/d/90/30000/fels\%C5\%91oktat\%C3\%A1si \%20koncepci\%C3\%B3.pdf Utolsó letöltés: 2016. november. 23.

5. Harsányi Gergely és Vincze Szilvia (2012): A magyar felsőoktatás néhány jellemzője nemzetközi tükörben. Pénzügyi Szemle, 2. 226-245. 